\title{
Assessment of Ijebu-Igbo Abattoir effluent and its impact on the ecology of the receiving soil and river.
}

\author{
Neboh, H.A. ${ }^{1}$, Ilusanya, O.A. ${ }^{2}$, Ezekoye C.C. ${ }^{1}$ and Orji, F.A ${ }^{3}$ \\ ${ }^{I}$ Department of Microbiology,University of Port Harcourt P.M.B. 5323, Choba, Rivers State, Nigeria. \\ ${ }^{2}$ Department of Microbiology, Olabisi Onabanjo University, P.M.B. 2002, Ago-Iwoye, Ogun State, Nigeria. \\ ${ }^{3}$ Enzymes and Genetics Division, Department of Biotechnology, Federal Institute of Industrial Research, \\ Oshodi, P.M.B. 21023, Ikeja, Lagos, Nigeria.
}

\begin{abstract}
The physicochemical and microbiological assessment of the waste water from a major abattoir at Ijebu-Igbo, Ijebu North local Government Area, Ogun State, Nigeria and its impact on the microbial population of the receiving soil and river were studied. The results of the physicochemical analysis showed that the effluent, the river water and contaminated soil parameters exceeded Water Environmental Federation (WEF) limitation guidelines for meat processing. Waste water $(\mathrm{Wb})$ from the butchering section had a higher bacteria count of $3.20 \times 10^{6} \mathrm{cfu} / \mathrm{ml}$ than waste water $(\mathrm{Wr})$ from the rinsing section with $2.21 \times 10^{6} \mathrm{cfu} / \mathrm{ml}$. The contaminated soil (Sc) had a higher value of $2.45 \times 10^{4} \mathrm{cfu} / \mathrm{g}$ than the uncontaminated soil (Suc) with $1.80 \times 10^{4} \mathrm{cfu} / \mathrm{g}$. On the other hand, the fungal count of the waste water sample $(\mathrm{Wb})$ from the butchering section had a lesser count of $1.16 x$ $10^{4} \mathrm{cfu} / \mathrm{ml}$ than waste water sample $(\mathrm{Wr})$ from the rinsing section with $1.18 \times 10^{4} \mathrm{cfu} / \mathrm{ml}$ while the uncontaminated soil (Suc) had a higher value of $1.22 \times 10^{4} \mathrm{cfu} / \mathrm{g}$ than the contaminated soil( $\mathrm{Sc}$ ) $1.12 \times 10^{4} \mathrm{cfu} / \mathrm{g}$. Bacteria isolated from both waste water and soil sample include Escherichia coli, Klebsiella pneumonia, Staphylococcus aureus, Proteus mirabilis, Serratia sp., Pseudomonas putida, Enterobacter aerogenes while the fungi isolated include Aspergillus niger, Torulopsis sp., Aspergillus fumigatus, Candida sp., Penicillum sp. and Saccharomyces cerevisae. Statistical analyses showed significance differences $(p<0.05)$ between the total bacterial count in the contaminated soil and the uncontaminated soil and also between the total bacteria count in the butchering and rinsing section. The corresponding values obtained for fungal count also showed a significant difference $(p<0.05)$ between the contaminated and uncontaminated soil while there was no significant difference $(p>0.05)$ between the butchering and the rinsing section. These results showed that a high microbial load in the Abattoir wastes had a negative effect in the microbial population in the soil and the river, hence the need to treat waste water before discharging into the ecosystem.
\end{abstract}

Key words: Abattoir, waste water, microbial population, soil, ecology.

\section{Introduction}

The Abattoir industry is an important component of livestock industry in Nigeria, providing domestic meat supplies to over 150 million people and employment opportunities for the teaming population [1]. An abattoir, also known as slaughter house is a place where animals are butchered for food according to Collins English dictionary. Abattoir acts (1985) defined an Abattoir as any premises used for or in connection with slaughter of animals whose meat is intended for human consumption and include a slaughter house but does not include a place situated on a farm. Abattoirs are known all over the world to pollute the environment either directly or indirectly from their various processes. Waste water from an abattoir is a particularly concentrated source of oxygen consuming wastes [2]. Abattoirs generally use large quantities of water for washing meat and cleaning process areas [3] and they are usually located near water bodies in order to gain access to water for processing. Contamination of river body and land from abattoir wastes could constitute a significant environmental and health hazard [4, 5, and 6]. Wastes from the slaughter house typically contain fat, grease, hairs, feathers, flesh, manure, grit and undigested feed, blood, bones and process water which is typically characterized with high organic level [4,5].The animal blood is released untreated into the flowing stream while the consumable parts of the slaughtered animal are washed directly into the flowing water [7]. The total amount of waste produced per animal slaughtered is approximately 35\% of its weight [8]. According to [9], abattoir effluents could increase levels of nitrogen, phosphorus, total solids in receiving water bodies considerably. Excess nutrients cause the water body to become choked with organic substances and organisms. When organic matter exceeds the capacity of the micro-organisms in water that breakdown and recycle the organic matter, it encourages rapid growth or blooms of algae leading to eutrophication.

Facilities for treatment of abattoir effluents are lacking unlike in developed countries where these facilities are adequately provided [10]. Improper disposal systems of wastes from slaughter houses could lead to transmission of pathogens to humans and cause zoonotic diseases such as Coli, Bacillosis, Salmonellosis, Brucellosis, and Helminthes [11]. Such contamination of water bodies could constitute significant 
environmental and public health hazards [4, 5, 6, and 8]. Bacteria from abattoir waste discharged into water bodies can subsequently be absorbed to sediments and when the bottom stream is disturbed, the sediments releases the bacteria back into the water columns presenting long term health hazards [12]. The consequences of infection by pathogens originating from animals wastes can range from temporary morbidity to mortality especially in high risk individuals.

Thus this study is aimed at assessing the microbiological and physicochemical qualities of Ijebu-Igbo abattoir effluent and its impact on the ecology of the receiving soil and river.

\subsection{Study Area.}

\section{Materials And Methods}

The Ijebu-Igbo abattoir, located at Ijebu-Igbo which is the headquarters of Ijebu North Local Government Area in Ogun State, Nigeria is located between latitude $6^{\circ}$ and $7^{\circ} \mathrm{N}$ and between longitude $3^{\circ}$ and $5^{\circ}$ east of the Greenwich Meridian. The slaughter house is located on about 12 hectares of land with its effluent discharged directly into the surrounding soil and river. The slaughter house is divided into different sections; the butchering section; where the animals are rendered; the rinsing section where the parts of the animals are rinsed and the dung pit where the intestines are emptied. About $120-170$ cows are killed everyday. The wastes from the abattoir are collectively discharged into the river and the soil without treatment, thus the significance of this research work.

\subsection{Sample collection}

Samples were collected from the abattoir for a period of two months. The abattoir was visited at 3 days interval to collect samples from each of the sections during the period. Samples were collected in the morning during the peak activities between 08.00 am and 09.00 am using a $500 \mathrm{~mL}$ sterilized Pyrex glass bottles with tight screw stoppers. Wastewater samples were collected at the abattoir from a point where it was thoroughly mixed and close to the discharging point $100 \mathrm{~mm}$ below the surface, samples from receiving water bodies were also collected $100 \mathrm{~mm}$ upstream and downstream (after mixing with the abattoir wastewater) respectively. The soil samples were collected both from the contaminated area and the uncontaminated area (to serve as control). Samples were transported to the laboratory in ice jackets and were processed within 4 hours of sampling. The samples were microscopically viewed under the microscope. The physicochemical analyses were carried out at the Institute of Agricultural Research \& Training (IAR\&T), Moor plantation, Ibadan, Oyo state, Nigeria.

\subsection{Microbiological analyses}

$10 \mathrm{~g}$ of the soil samples were crushed, air dried and diluted in $90 \mathrm{ml}$ of sterile distilled water, while $10 \mathrm{ml}$ of the waste water samples were diluted in $90 \mathrm{ml}$ of sterile distilled water instead. The serial diluents were aseptically inoculated onto different plates of melted sterile medium after cooling to $45^{\circ} \mathrm{C}$ and glass spreader was used to spread the inoculums. The media used include Potato Dextrose Agar (PDA), Nutrient Agar, Centrimide Agar, MacConkey Agar, Robertson's cooked meat medium, Malt Extract Agar (MEA), Man, Rogosa and Sharpe (MRS) medium and Eosin Methylene Blue (EMB) Agar. In estimating total fungi, PDA plates supplemented with streptomycin $(100 \mathrm{ug} / \mathrm{ml})$ to inhibit bacteria growth were aseptically inoculated with serial diluents $\left(10^{-2}-10^{-6}\right)$ and incubated at $30^{\circ} \mathrm{C}$ for $72 \mathrm{hr}$. In estimating total bacteria, sterile nutrient agar were aseptically inoculated with aliquot of serial diluents $\left(10^{-4}-10^{-9}\right)$ of the samples and incubated at $37^{\circ} \mathrm{C}$ for $24 \mathrm{hr}$. After incubation the number of colonies on the plates with distinct growth were estimated and recorded as colony-forming units per milliliter $(\mathrm{CFU} / \mathrm{ml})$. Subculturing was done until distinct colonies were obtained. In identifying fungi, microscopic and macroscopic examinations including staining for morphological characteristics were carried out on fungal isolates and identification was done based on the characteristics. For bacteria, pure isolates were isolated and identified using biochemical tests [13, 14].

\subsection{Physicochemical parameters}

The standard analytical methods that were used for determination of physicochemical parameters of the samples were from American Public Health Association series of Standard Methods of Examination of Water and Effluent [15] and results were compared with [16].

\subsection{Analysis of data}

The results of the laboratory analysis were subjected to data analysis using SPSS, version 12 . The microbial concentrations obtained were compared $(\mathrm{P}<0.05)$ using the one-way Analysis of Variance (ANOVA) to establish if there were any relationship. 


\section{Results And Discussion}

The physicochemical parameters and microbial population shown in tables 1, 2 and 3 measured in this study showed to a larger extent the quality and types of pollutants and micro-organisms present as a result of the abattoir effluent discharged into the river and the soil from the slaughter house.

Table 1 : The mean value of the physicochemical analysis of waste water samples from Ijebu-Igbo Abattoir.

\begin{tabular}{lll}
\hline Parameters & $\begin{array}{l}\text { Butchering } \\
\text { section }(\mathbf{W b})\end{array}$ & $\begin{array}{l}\text { Rinsing } \\
\text { section }(\mathbf{W r})\end{array}$ \\
\hline $\mathrm{pH}$ & 9.6 & 4.2 \\
Temperature $\left({ }^{0} \mathrm{C}\right)$ & 34 & 32 \\
Total Dissolved Solids $(\mathrm{mg} / \mathrm{l})$ & 986.2 & 282.5 \\
Conductivity $(\Omega / \mathrm{cm})$ & 978.2 & 196.3 \\
Total Suspended Solids(mg/l) & 367.6 & 29.4 \\
Biological Oxygen Demand(mg/l) & 623.35 & 261.63 \\
Chemical Oxygen Demand $(\mathrm{mg} / \mathrm{l})$ & 77.3 & 32.2 \\
Zinc $(\mathrm{mg} / \mathrm{l})$ & 55.8 & 0.02 \\
Turbidity \% & 288.2 & 21.3 \\
Manganese $(\mathrm{mg} / \mathrm{l})$ & 0.26 & 0 \\
Aluminum $(\mathrm{mg} / \mathrm{l})$ & 967.3 & 0.46 \\
Iron $(\mathrm{mg} / \mathrm{l})$ & 86.38 & 6.2 \\
Ammonia $(\mathrm{mg} / \mathrm{l})$ & 73.2 & 7.8 \\
Copper $(\mathrm{mg} / \mathrm{l})$ & 9.6 & 0.2 \\
Lead $(\mathrm{mg} / \mathrm{l})$ & 0.06 & 0 \\
Mercury $(\mathrm{mg} / \mathrm{l})$ & 69.6 & 28.7 \\
Nitrate $(\mathrm{mg} / \mathrm{l})$ & 118,978 & 16.76 \\
Total Nitrogen $(\mathrm{mg} / \mathrm{l})$ & 48.6 & 12.69 \\
Phosphate $(\mathrm{mg} / \mathrm{l})$ & 1246 & 413.2 \\
\hline
\end{tabular}

The mean total bacteria count and fungal count were high for the water samples. Going by [16], any water contaminated to this level is neither good for domestic use nor is supposed to be discharged directly into the environment without treatment. The $\mathrm{pH}$ of the waste water and soil samples ranged from acidic to alkaline (4.2 - 10.5), this plays a part in determining both the qualitative and quantitative abundance of micro flora [17]. It could be inferred then that more hydrogen ion became available, lowering the $\mathrm{pH}$ value of contaminated soil and affecting the pattern of microbial population. This can be supported by the report of [18] that abundance and activity of micro flora in soil strata are controlled by the availability of water, nutrients, $\mathrm{pH}$, concentration of metal ions and hydrogen dynamic communication with the ground surface. The high level of turbidity in the water sample may result in unpleasant colour of water and may also be harmful and this is indicative of the presence of colloidal solids and large number of micro-organisms. Turbidity on the other hand influences the penetration of light, which in turn affects the photosynthetic activity of plants and productivity of the river.

The temperature of the waste water from the butchering section was found to be higher than that from the rinsing section by $2^{\circ} \mathrm{C}$. This could be attributed to the decomposition of the organic waste by the microorganism. Decomposition produces heat from the anaerobic respiration of the bacteria [19].

Heavy metals are natural constituents of the earth crust. Living organisms require trace amount of some heavy metals including cobalt, copper, iron, manganese and zinc. Excess levels of essential metals however can be detrimental to living organisms. Since they cannot be degraded or destroyed, therefore they tend to accumulate in the soil and sediment. Mercury which is a non- essential metal poses great risk to human. Bacteria in the water causes chemical changes that transform mercury to methyl mercury which binds tightly to the fish tissue, consumption of this can lead to mercury poisoning. High amount of mercury can damage the nervous system of the consumer triggering health problems like memory loss, slurred speech, lack of co-ordination, loss of sensation in fingers and toes, reproductive problems, coma and possibly death. Leaching of these heavy metals into the ground water is also a major cause of concern especially due to the recalcitrant nature of the metals [20]. Presence of excess copper can cause anemia, liver and kidney damage, stomach and intestinal irritation. 
Table 2: The mean value of the physicochemical analysis of soil samples from Ijebu- Igbo Abattoir.

\begin{tabular}{lll}
\hline Parameters & $\begin{array}{l}\text { Contaminated } \\
\text { soil (Sc) }\end{array}$ & $\begin{array}{l}\text { Uncontaminated } \\
\text { soil (Suc) }\end{array}$ \\
\hline $\mathrm{pH}$ & 10.5 & 4.6 \\
Calcium $(\mathrm{mol} / \mathrm{kg})$ & 2.75 & 1.78 \\
Magnesium $(\mathrm{mol} / \mathrm{kg})$ & 6.25 & 3.58 \\
Sodium $(\mathrm{mol} / \mathrm{kg})$ & 0.58 & 0.27 \\
Potassium $(\mathrm{mol} / \mathrm{kg})$ & 0.84 & 0.39 \\
Available Phosphate $(\mathrm{mol} / \mathrm{kg})$ & 5.64 & 3.28 \\
\% Organic Carbon & 6.82 & 3.74 \\
\% Nitrogen & 3.85 & 1.26 \\
\% Organic Matter & 11.76 & 6.45 \\
Iron (mg/kg) & 96.8 & 21.5 \\
Zinc (mg/kg) & 21.6 & 18.7 \\
Copper (mg/kg) & 19.2 & 6.6 \\
Manganese (mg/kg) & 187.2 & 118.3 \\
Cation Exchange (mol/kg) & 16.84 & 12.54 \\
\% sand & 83.62 & 89.39 \\
\% silt & 8.94 & 6.85 \\
\% Clay & 7.44 & 3.76 \\
\hline
\end{tabular}

The presence of nitrate and phosphorus can be attributed to the feed of the cow. The high concentration of nitrate can be attributed to the high concentration of organic matter content of the samples and as a result of the decomposition of protein and nitrogenous compound which when broken down gives rise to simpler substances like ammonia. The value of BOD of the waste water sample from the butchering section $\mathrm{Wb}$ $(623.35 \mathrm{mg} / \mathrm{l})$ and waste water sample from the rinsing section $\mathrm{Wr}(261.63 \mathrm{mg} / \mathrm{l})$ were high compared to the BOD standard $(50 \mathrm{mg} / \mathrm{l})$ of [16]. This increase resulted into the depletion of oxygen which is utilized by the microorganisms for the breakdown of organic matter and thus actively encourage the growth of anaerobic than aerobic organisms [19]. When oxygen becomes less available, it prompts denitrifying bacteria to reduce available nitrate to gaseous nitrogen that enters the atmosphere with a resultant negative effect [21]. The level of sodium ions when in excess disperses fine particles into pores, reducing water penetration and blocking root access. High level of calcium salt reduces erosion and when the nitrogenous content of the soil is high, microbial presence is greatly enhanced, this will promote plant's growth while a shortage in nitrogen content or poor organic matter content result in a drought of microbes in soil thus affecting plant's growth negatively [22].

Table 3: Microbial isolates from the soil and waste water samples

\begin{tabular}{|c|c|c|}
\hline Samples & Bacteria & Fungi \\
\hline \multirow[t]{2}{*}{$\mathrm{Wb}$} & Eschericia coli, Klebsiella pneumoniae, & Aspegillus niger, Candida sp. \\
\hline & Staphylococcus aureus, Proteus mirabilis & Saccharomyces sp., \\
\hline \multirow[t]{2}{*}{$\mathrm{Wr}$} & Eschericia coli, Staphylococcus aureus & Aspegillus niger, Candida sp. \\
\hline & Serratia sp., Pseudomonas putida & Penicillium sp., Aspergillus fumigatus \\
\hline Sc & Klebsiella pneumoniae, Serratia sp. & Aspegillus niger, Torulopsis sp., \\
\hline Suc & $\begin{array}{l}\text { Proteus mirabilis, Pseudomonas putida } \\
\text { Klebsiella pneumoniae, Enterobacter aerogenes, } \\
\text { Staphylococcus aureus }\end{array}$ & $\begin{array}{c}\text { Saccharomyces sp., Aspergillus, fumigatus } \\
\text { Torulopsis sp., Rhizopus sp. } \\
\text { Saccharomyces sp. }\end{array}$ \\
\hline
\end{tabular}

Legend: Wb; waste water from butchering section, $\mathbf{W r}$; waste water from rinsing section, $\mathbf{S c}$; contaminated soil, Suc; uncontaminated soil.

The result of the microbial population in Figures 1 and 2, showed that both waste water from the butchering section $(\mathrm{Wb})$ and contaminated soil $(\mathrm{Sc})$ had a higher count of bacteria and this may be due to high concentration of micro-organisms as a result of the presence of nutrients in the effluent in which the microorganisms thrive. The results also showed that occurrence of enteric organisms like Escherichia coli and Enterobacter aerogenes which belong to the group Enterobacteriaceae, is indicative of faecal contaminations as they are normal inhabitants of intestinal tracts of human and other animals. Most of the isolated bacteria are pathogens; a good example is Staphylococcus aureus which causes food poisoning, skin infections and urinary tract infection. Another example is Klebsiella pneumonia which also causes urinary tract infection. 
Pseudomonas putida is liable to survive and multiply in almost any moist situation and cause extensive rashes. Food borne diseases caused by $E$. coli occurs in most slaughter houses due to their unhygienic practices especially when the cow meat comes in contact with faecal material.

The fungal populations isolated are opportunistic fungi; examples are Aspergillus niger, Saccharomyces cerevisae, Aspergillus fumigatus. The Aspergillus sp. are usually found when organic debris abounds and can cause Aspergillosis in human, cattle, and poultry. Inhalation of Aspergillus sp. can result in Asthma with difficulty in breathing. A large Aspergilloma in the lungs can block respiratory gas exchange and cause death due to asphyxiation [23]. Rhizobium sp. on the other hand can infect leguminous plant roots, where they cause formation of tumorous growth root nodules with which they live in a mutually beneficial relationship with leguminous plant thus enhancing their growth.

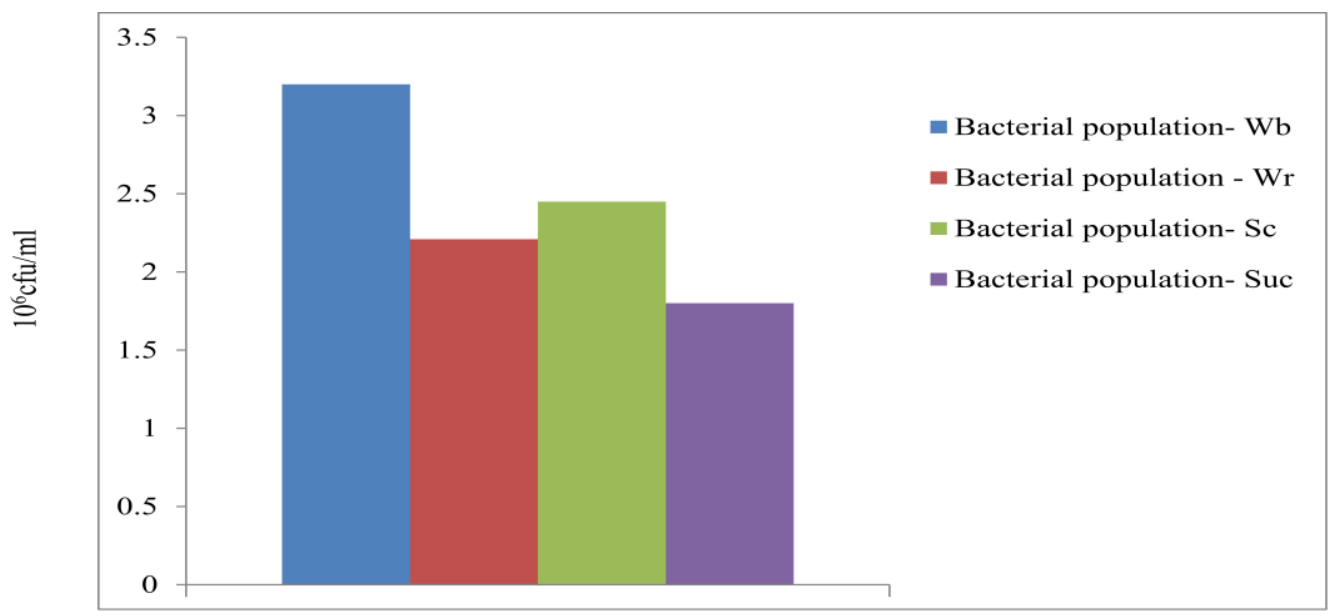

Figure 1. Bacterial population in butchering section-Wb, Rinsing section-Wr ; in contaminated soil- Sc, Uncontaminated soil- Suc.

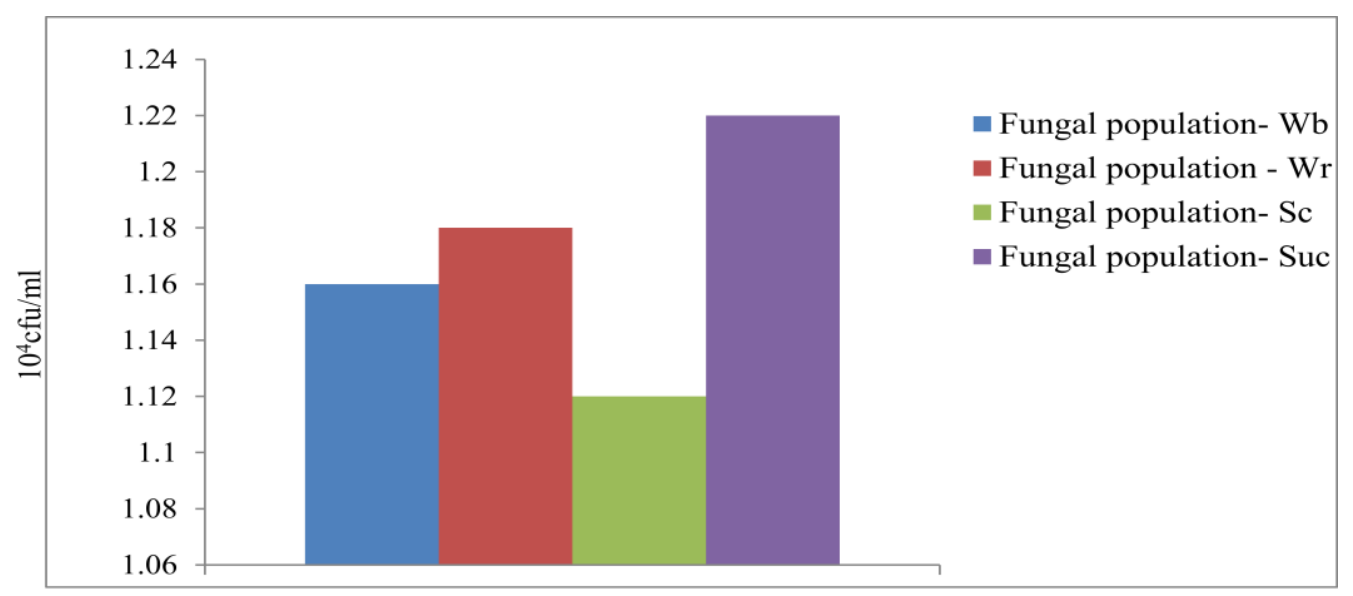

Figure 2. Fungal population in butchering section-Wb, Rinsing section-Wr ; in contaminated soil- Sc, Uncontaminated soil- Suc.

The total bacterial population obtained from the contaminated soil (Sc) $2.45 \times 10^{6}$ was greater than that in the soil without waste water contamination (Suc) $1.80 \times 10^{6}$. The fungi count in the uncontaminated soil, 1.22 x $10^{4}$ were more than that of contaminated soil, $1.12 \times 10^{4}$. This could be regarded as destabilization of the soil ecological balance arising from contamination [24]. Another possible explanation of this is that the organism in the water was discharged into the soil and guided by the law of survival of the fittest [21], those that were not able to survive the new condition were probably excluded. Higher population of bacteria observed in the contaminated soil was possibly due to their ability to withstand alkaline conditions and the higher fungi in the uncontaminated soil was also due to their ability to withstand a high acidic condition [25]. One way ANOVA test showed that there was significant difference $(p<0.05)$ between the total bacteria count in the contaminated soil and the uncontaminated soil; and also between the total bacteria count in the butchering section and the rinsing section. For the fungal counts, there was significant difference between the contaminated and 
uncontaminated soil while there was no significant difference at $(\mathrm{p}>0.05)$ between the butchering section and the rinsing section.

\section{Conclusion}

The high level of contamination of Ijebu-Igbo abattoir waste water and its contaminated soil as obtained in this study further confirmed the dangers associated with discharging untreated waste water to the soil and river, thus the need for adequate treatment to ensure decontamination. Considering the present demand for livestock due to growth in population and requirement on health grounds for meeting up with the calcium and protein requirements of the population, sustainability in meat production should be given priority of place since it intertwines with public health and economic development.

\section{Recommendations}

- It is recommended that better inspection of abattoirs and strict enforcement of law be made to be able to reduce environmental contamination and related diseases especially zoonotic diseases.

- Attempts should also be made to control the hygiene of slaughter house using visual assessment of premises and animals themselves, and those that are visibly unacceptably dirty or affected by diseases should not be allowed for slaughter.

- Government agencies and other stake holders should develop methods of waste treatments for reasons of public health and conservation which result in the destruction of pathogens. Such methods can include anaerobic waste water treatment using granular sludge reaction.

- Finally, solid waste from slaughtered animals can be fermented in tanks to produce compost and biogas. Biogas can be used as additional energy for the production of industrial and household gas. Thus, encouraging sustainable agriculture.

[1] W.D. Nafarnda, I.E. Ajayi, J.C. Shawulu, M.S. Kawe, G.K. Omeiza, N.A. Sani, O.Z. Tenuche, D.D. Dantong and S.Z. Tags, Bacteriological quality of Abattoir effluents discharged into water bodies in Abuja, Nigeria. ISRN Vet. Sci. 2012, article I.D515689.

[2] J. Girards, Principle of Environment Chemistry, Jones \& Bartlett, USA. 2005, Pp. 12-23.

[3] M.S. Kuyeli, Assessment of Industrial Effluent and their Impact on water quality of Streams in Blantyre, (Msc. Thesis) Unima, Zomba, 2007.

[4] A.O. Coker, B.O. Olugasa, and A.O. Adeyemi, "Abattoir and wastewater quality in South Western Nigeria," in Proceedings of the 27th Water, Engineering and Development Centre Conference, Lusaka, Zambia, 2001.

[5] W. D. Nafarnda, A. Yaji, and H. I. Kubkomawa, "Impact of abattoir waste on aquatic life: a case study of Yola abattoir," Global J. Pure and Appl. Sci. vol. 12:2006, 31-33.

[6] O. Osibanjo and G. U. Adie, "Impact of effluent from Bodija abattoir on the physicochemical parameters of Oshunkaye stream in Ibadan City, Nigeria," Afri. J. Biotechnol. 6(15):2007, 1806-1811.

[7] J.A. Adelegan, Environmental policy and slaughterhouse waste in Nigeria. Proceedings of then 28th WEDC Conference, Calcutta, India, 2002, pp. 3-6

[8] World Bank, "Poor Management of Processing Wastes. Environmental Assessment: Pressure State Response Indicators," Pollution Prevention and Abatement Handbook, 1998.

[9] D.O Omole and E.O. Longe, an assessment of the impact of abattoir effluents on River Illo, Ota, Nigeria. J. Environ. Sci. and Technol. 1(2):2008, 56-64.

[10] C. Obgonnaya, "Analysis of groundwater pollution from abattoir waste in Minna, Nigeria,"Res. J. Dairy Sci. 2(4): 2008 , 74-77.

[11] S. I. Cadmus, B. O. Olugasa, and G. A. Ogundipe, "The prevalence and zoonotic importance of bovine tuberculosis in Ibadan," in Proceedings of the 37th Annual Congress of the Nigerian Veterinary Medical Association, 1999, pp. 65-70.

[12] B. M. Sherer, R. J. Miner, J. A. Moore, and J. C. Buckhouse, "Indicator bacterial survival in stream sediments," J. Environ. Qual. 21(4): 1992, 591-595.

[13] J.G. Cappuccino, N. Sherman. Standard qualitative analysis of water. In: Microbiology: A laboratory manual. $5^{\text {th }}$ ed. Benjamin/Cumming publishing Co, England, 1998, pp 297- 303.

[14] Anon. Bergey's manual of determinative bacteriology. Holt JG, Krieg NR, Sneath PHA, Staley JT, Williams ST (ed). Williams and Wilkins, Baltimore, USA, 1994.

[15] American Public Health Association (APHA). Standard methods for examination of water and wastewater. American Public Health Association, American Water Works Association and Water Environment Federation. 20 ${ }^{\text {th }}$ edn. Washington DC, USA, 1998, pp. 5-7.

[16] Water Environment Federation, American Public Health Association, American Water Works Association (1998). Water quality standards, $20^{\text {th }}$ edn. Washington DC, USA, 1998.

[17] A.Y. Federov, E.V. Volchenko, V.I. Korzhenerich, I.N. Singirtser, V.Y. Krest'yaninov. A polysubstrate strain that degrades wastewater components of phenol production. J. Appl. Biochem. Microbiol. 29:1993, 532-536.

[18] T.N. Nazina, A.A Corigor'yan, Y. Xue, D.S. Sokolova, E.V. Novikova, T.P. Yourova, A.B. Poitaraus, S.S. Balyaer and M.V. Ivanor, Phylogenetic diversity of aerobic saprotrophic bacteria isolated from daging oil field. Microbiol.71:2002, 91-97.

[19] Y. A Matilukuro. Microbial content of abattoir wastewater and its effect on Ogun river. A Bsc. thesis of the Department of Microbiology. Olabisi Onabanjo University, Ogun state, 2003, pp.10-16.

[20] A. Laukova, M. Marekova , Z. Vasilkova, I. Papajova and P. Juris P, Selected microbial consortium of raw and digested slurry and its susceptibility to enterocins. World J. Microbial. Biotechnol. 18:2002, Pp.11-15. 
[21] M.T. Madigan, J.M. Martinko and J. Parker, Brock biology of microorganisms. International edition. Prentice Hall intern Ltd., London. 2003, pp.1020-1040.

[22] L.D. Norton, S. Hainberg, L. Gweck, J.R. Edwards and H. James, H, Erosion and soil chemical properties. An Msc. Thesis, University of Agriculture, Uganda, 2002, pp.15-17.

[23] M.A. Ronald, Microorganisms in our world. Library of congress cataloging in publication data. $4^{\text {th }} \mathrm{Ed} .2003$, Pp.40 -52.

[24] J. Borneman, P.W.Skroch, K.M. Sullivan, J.A. Palus, N.G. Rumjanek, J. Jansen, J. Neinhuis, and E.W.Triplett. Molecular microbial diversity of an agricultural soil in Wisconsin. Appl. Environ. Microbiol. 62:1996, 1935-1943.

[25] R.T. Hill, W.L. Straube, A.C. Palmisano, S.L. Gibson and R.R.Colwell. Distribution of sewage indicated by Clostridium perfringens at a deep water disposal site after cessation of sewage disposal. Appl. Environ. Microbiol. 62:1996, 1741-1746. 